\title{
EFFECT OF ADDITIVE ON THE PROCESS PARAMETERS AND COAGULATION IN A PRODUCTION OF FETA CHEESE
}

\author{
Vojkan M. Miljković ${ }^{1}$, Milena N. Miljković ${ }^{2} \&$ Violeta Rakić $^{3}$ \\ ${ }^{1}$ Department of Pharmacy, Faculty of Medicine, University of Niš \\ Bulevar Dr Zoran Djindjić 81, 18000 Niš, Serbia, phone: +381 184238770 \\ ${ }^{2}$ Department of Chemistry, Faculty of Science and Mathematics, University of Niš \\ Višegradska 33, 18000 Niš, Serbia, phone: +381 654292621, e-mail: milenabmv@gmail.com \\ ${ }^{3}$ College of Agriculture and Food Technology, Ćirila i Metodija 1, 18400 Prokuplje, Serbia \\ phone: +38127/324-311, +38169 8702552, e-mail: violetachem@gmail.com
}

\begin{abstract}
Milk and milky products are multycomponent systems. The technology of milk processing mostly depends on the ways of separating these components. In addition to classic methods of separation (evaporation, suction and distillation), modern methods allows separation similiar compounds and mixtures that are sensitive to temperature changes, $\mathrm{pH}$, light, etc. The most important separation processes are: reverse osmosis, microfiltration and ultrafiltration. The membrane technique of the ultrafiltration process is the separation of the components of one solution depending on its molecular size (10-1000). In the process of milk tetrating, two separate fractions are obtained: retentate - a fraction containing proteins with minimal amounts of lactose and mineral matter and permeate - fraction containing lactose, mineral matter, non-protein nitrogen, free amino acids and vitamins. In this paper, the results of physical and chemical testing of feta in the process of ripening after 15 days, after a month, after month and a half and after 2 months are presented. The results of the material balance in feta are also given in the paper. They are calculated by the relationship between the standard quantity of milk (100 I) and the amount of feta cheese that is obtained as the final product after ripening.
\end{abstract}

Keywords: feta, cheese, ultrafiltration, retentate, permeate.

\section{INTRODUCTION}

This paper presents the process of production of feta cheese, which is described on the basis of the technological process in the former cheese fabric "Džersi" DOO in Knjaževac, with special emphasis on the influence of parameters and additives on the process of coagulation in the production of feta cheese.

\section{EXPERIMENTAL}

\subsection{Physical - chemical methods for milk testing}

\subsubsection{Determination of milk acidity by SOXHLET - HENKEL}

Acidity by SOXHLET - HENKEL is number of $\mathrm{cm}^{3} 1 / 4 \mathrm{NaOH}$ necessary for neutralization 100 $\mathrm{cm}^{3}$ milk with phenolphthalein as an indicator. Equipment: pipette of $20 \mathrm{~cm}^{3}$, birette, Erlenmeyer of $100 \mathrm{~cm}^{3}$. Chemicals: $1 \mathrm{M} \mathrm{NaOH}, 2 \%$ alcoholic solution of phenolphthalein. Work flow: Measure $20 \mathrm{~cm}^{3}$ of milk in the Erlenmeyer of $100 \mathrm{~cm}^{3}$, add 2-3 caps of phenolphthalein and start titration with $1 \mathrm{M} \mathrm{NaOH}$ to the appearance of a pale pink color that is not lost for 2 minutes. Number of spent milliliters of $1 \mathrm{M} \mathrm{NaOH}$ multiplied by 2 is ${ }^{\circ} \mathrm{SH}$ of tested milk. 


\subsubsection{Determination of milk fat by GERBER}

Equipment: stand for tubes, butyrometers for milk, elastic rubber belt, pipettes of $10 \mathrm{~cm}^{3}$ for milk, $\mathrm{H}_{2} \mathrm{SO}_{4}$ and amyl alcohol, water bath, centrifuge. Chemicals: $\mathrm{H}_{2} \mathrm{SO}_{4}$, amyl alcohol. Work flow: Carefully measure $10 \mathrm{~cm}^{3}$ of $\mathrm{H}_{2} \mathrm{SO}_{4}$ and pour into the butyrometer in the stand where are the tubes with samples. Since the milk test is a good mix, measure $11 \mathrm{~cm}^{3}\left(T=20^{\circ} \mathrm{C}\right)$ and pour into the butyrometer. Then add $1 \mathrm{~cm}^{3}$ of amyl alcohol. After closing the butyrometer, place it in a water bath with temperature of $65^{\circ} \mathrm{C}$. Before centrifuging the dots, the upper edge of the contents of the butyrometer to the last section on the scale and then the centrifugation is performed for 5 minutes, at speeds of 1200 turns $/ \mathrm{min}$. After 5 minutes turn off the centrifuge and the butyrometer are removed and refer to the water bath on 65․ After 3-5 minutes, the plunger cuts off the thickness of the fatty column to one of the main lines and points. The diference between the lower and upper menisc of the fatty column is the milk fat in \%.

\subsubsection{Determination of specific milk weight by lactodenzimeter}

Under the specific weight of milk, it is understood that the milk is at a temperature of $20^{\circ} \mathrm{C}$ weight percent of distilled water of the same volume and temperature. Equipment: lactodenzimeter, scale of $300 \mathrm{ml}$. Work flow: Along the wall of scale gently pour $300 \mathrm{ml}$ of milk into the foam, so that the foam can read the specific weight. Then lightly lower the lactodenzimeter into milk up to the mark 30 on the scale. When the lactodenzimeter calm down, read the lactodenzimeter number at the height of the upper meniscus. The specific milk weight should be measured at a temperature between $15^{\circ} \mathrm{C}$ and $20^{\circ} \mathrm{C}$ with correction being done. They are arranged so that for each degree lower than 20 take it away and higher than 20 added 0,2 .

\subsubsection{Determination of dry milk content by FLEISCHMANN}

It is carried out using the formula based on the results obtained for $\%$ of fat milk and specific milk weight.

$C=1,2 \times f+2,665(100 d-100 / d)$,

$\mathrm{C}-\%$ of dry milk content; $f-\%$ of milk fat; $d-$ specific milk weight.

\subsubsection{Determination of dry milk content without fat}

Dry milk content without fat is represents a fairly stable milk constant used to prove and determine falsification of milk by adding water. \% of dry milk content without fat is obtained by subtracting $\%$ of milk fat and the dry milk content.

\subsubsection{Determination of milk quality by fermentation test by $A$. Peter}

Fermentation test is a simple practical test by which court is passed on measures to be taken in the technological process in order to obtain a better quality. Equipment: tubes, cover for tubes made of galvanized sheet metal, metal stand, water bath. Work flow: In the tube, milk is poured up to $1 \mathrm{~cm}^{3}$ of the upper edge of the tube and covered with a lid. As other tubes are filled up, the stand with the tubes is lowered to a water bath at a temperature of about 38$40^{\circ} \mathrm{C}$. The first observation of the test is done after $12 \mathrm{~h}$, the second after $15-16 \mathrm{~h}$ and the final third after $24 \mathrm{~h}$. Based on the observed changes in milk after the last observation, a table comparate with the Peter's test table and determine the fermentation properties of milk for making feta.

\section{IRTIIE Vol. 6, No. 4, 2018 ISSN 1314-8788 (print), ISSN 1314-8796 (online), doi: 10.15547/artte.2018.04.011}




\section{IR'TIE \\ Ipplied Resererrches in Technics, Technologies ind Eductition \\ Journal of the Faculty of Technics and Technologies, Trakia University https://sites.google.com/a/trakia-uni.bg/artte/}

\subsubsection{Alcoholic test for determining acidity of milk in ${ }^{\circ} \mathrm{SH}$}

Pipette $2 \mathrm{ml}$ of milk, transfer to the tube, heat a little, add $2 \mathrm{ml}$ of $75 \%$ etyl alcohol and mix it. If there are flakes, then milk cannot be used as sterile, because it has a higher degree of acidity. Up to $8^{\circ} \mathrm{SH}$ reaction is negative, milk is suspicious, but not grub. Over $8^{\circ} \mathrm{SH}$ reaction is positive and milk is sour.

\subsubsection{Examination on the presence of carbonates}

Rosaceal acid is used to examine the falsification of milk when carbonates is added in milk. Equipment: normal court of $500 \mathrm{ml}$, glass stick, Erlenmeyer of $300 \mathrm{ml}$, veggel, glass leak. Chemicals: Rosaceal acid, etyl alcohol. Work flow: In a veggel measure $1 \mathrm{~g}$ of rosaceal acid and transfer to normal court with glass stick and Erlenmeyer. Add etyl alcohol to the line and mix well. Color is being watched. Milk without soda $(\mathrm{NaOH})$ will be dull yellow while milk with soda will be dull red. Rosaceal acid with alcohol is an indicator.

\subsection{Psysical - chemical methods for feta cheese}

\subsubsection{Determination of acidity by THORNER}

Equipment: porcelain avan with a fist, birette. Chemicals: $1 \mathrm{M} \mathrm{NaOH}, 2 \%$ of alcohol solution of phenolphthalein. Work flow: Acidity of milk by THORNER is number of milliliters $1 \mathrm{M} \mathrm{NaOH}$ consumed to neutralize $100 \mathrm{~g}$ cheese, with indicator phenolphthalein. Measure $5 \mathrm{~g}$ of cheese on a technical scale. Put in a porcelain avan and rub it with a fist. Then add $100 \mathrm{ml}$ distilled water in small quantities and mix well with cheese. Titrate the resulting emulsion with $\mathrm{NaOH}$ with phenolphthalein until a pale red color appears, which will not be lost within 2 minutes.

\subsubsection{Determination of $\%$ fat of feta cheese by butyrometric method by GERBER - SIEGFELD}

Equipment: Erlenmeyer of $30 \mathrm{~cm}^{3}$, butyrometer for milk, water bath, leak, centrifuge. Chemicals: $\mathrm{HCl}$ with specific weight of 1,125 , amyl alcohol. Work flow: $2-2,5 \mathrm{~g}$ of chopped cheese is placed in an erlenmeyer, add $10 \mathrm{~cm}^{3}$ of $\mathrm{HCl}$ and heat. During heating, the contents are spilled into the butyrometer for milk, spills with $1 \mathrm{~cm}^{3}$ of amyl alcohol, the butyrometer is clogged, then it's mix for 2-3 minutes, then it comes in the same way as when determining fat by Gerber.

$\%$ fat $=m \times 11,33 / A$, $\mathrm{m}-\%$ fat read on butyrometer; $\mathrm{A}-$ weight of cheese in grams.

\subsubsection{Determination of the content of kitchen salt in feta}

Equipment: porcelain trowel, leak, filter paper, birette, erlenmeyer. Chemicals: $1 \mathrm{M} \mathrm{AgNO}_{3}$, $5 \%$ solution of $\mathrm{K}_{2} \mathrm{CrO}_{4}$. Work flow: In a porcelain trowel add $2-3 \mathrm{~g}$ cheese and heat to charcoal cheese mass, then a smaller amount of distilled water is poured and the contents filtered. Filtrate is caught in a glass. For each $50 \mathrm{~cm}^{3}$ of the obtained filtrates, $1 \mathrm{~cm}^{3}$ solution of $\mathrm{K}_{2} \mathrm{SO}_{4}$ was added as an indicator, well titrate with $1 \mathrm{M} \mathrm{AgNO}_{3}$ until the appearance of cigills colour.

$X=b \times 0,00585 / a \times 100$,

$\mathrm{X}-\%$ of $\mathrm{NaCl} ; \mathrm{b}-$ weight of cheese in grams; $\mathrm{a}$ - amount of $\mathrm{AgNO}_{3}$ in $\mathrm{cm}^{3}$.

\subsubsection{Determination of water content in cheese}

Take $20 \mathrm{~g}$ of quartz sand and about $5 \mathrm{~g}$ of cheese and dry it to $105-110^{\circ} \mathrm{C}$ to constant weight.

IRTIIE Vol. 6, No. 4, 2018 ISSN 1314-8788 (print), ISSN 1314-8796 (online), doi: 10.15547/artte.2018.04.011 


\subsubsection{Determination of the $\%$ of dry matter in cheese}

Under dry cheese matter is the remainder after drying the sample at $103^{\circ} \mathrm{C}$ to constant weight. Equipment: $\mathrm{Ni}$ or $\mathrm{Al}$ cup with sand which is washed with $\mathrm{HCl}$ and water and then heated, glass stick. Work flow: Place around $30 \mathrm{~g}$ of sand and glass stick in a cup, then dry in dryer at $105^{\circ} \mathrm{C}$. Cool the cup in the desiccator and measure it on the analytical balance. Repeat the drying and measurement with alternating cooling to constant weight. Then put $3 \mathrm{~g}$ of cheese into a cup and re-measure it. Mix the sample cheese well with a glass stick with sand, then dry in a dryer at $105^{\circ} \mathrm{C}$ for $3-4 \mathrm{~h}$. In the event of an increase in weight, the weight is taken before the increase.

$\%$ of dry matter $=a \times 100 / b$,

$a$ - the rest after drying; $b$ - weight of the measured sample. The maximum allowed difference between the two samples may be $+/-0,1 \%$.

\section{RESULTS}

\subsection{Results of milk quality testing}

\subsubsection{Physical - chemical tests}

The Table 1 shows that milk acidity is moving at the border $6.8-7.2{ }^{\circ} \mathrm{SH}$, the mean value of milk acidity is $7.0^{\circ} \mathrm{SH}$.

Table 1 .The results of milk acidity testing used for making feta

\begin{tabular}{|l|l|l|l|l|l|l|l|}
\hline \multicolumn{2}{|l|}{ Milk acidity -SH } \\
\hline $\begin{array}{l}\text { Beli } \\
\text { potok }\end{array}$ & $\begin{array}{l}\text { Donje } \\
\text { zuniče }\end{array}$ & $\begin{array}{l}\text { Gornje } \\
\text { zuniče }\end{array}$ & Kalna & Vasilj & Tupižnica & Vina & $\begin{array}{l}\text { Middle } \\
\text { value }\end{array}$ \\
\hline Test 1 & Test 2 & Test 3 & Test 4 & Test 5 & Test 6 & Test 7 & \\
\hline 7.2 & 7.0 & 7.0 & 6.8 & 7.2 & 7.2 & 6.8 & 7.0 \\
\hline
\end{tabular}

Table 2. The results of fat milk

\begin{tabular}{|l|l|l|l|l|l|l|l|}
\hline \multicolumn{2}{|l|}{ Milk fat in \% } \\
\hline $\begin{array}{l}\text { Beli } \\
\text { potok }\end{array}$ & $\begin{array}{l}\text { Donje } \\
\text { zuniče }\end{array}$ & $\begin{array}{l}\text { Gornje } \\
\text { zuniče }\end{array}$ & Kalna & Vasilj & Tupižnica & Vina & $\begin{array}{l}\text { Middle } \\
\text { value }\end{array}$ \\
\hline Test 1 & Test 2 & Test 3 & Test 4 & Test 5 & Test 6 & Test 7 & \\
\hline 3.79 & 3.93 & 3.93 & 3.69 & 3.89 & 3.80 & 3.92 & 3.84 \\
\hline
\end{tabular}

The Table 2 shows that milk fat is moving at the border 3.69-3.92, the mean value of milk fat is $3.84 \%$.

Table 3. The results of specific milk weight

\begin{tabular}{|l|l|l|l|l|l|l|l|}
\hline \multicolumn{2}{|l|}{ Specific milk weight in g/l } \\
\hline $\begin{array}{l}\text { Beli } \\
\text { potok }\end{array}$ & $\begin{array}{l}\text { Donje } \\
\text { zuniče }\end{array}$ & $\begin{array}{l}\text { Gornje } \\
\text { zuniče }\end{array}$ & Kalna & Vasilj & Tupižnica & Vina & $\begin{array}{l}\text { Middle } \\
\text { value }\end{array}$ \\
\hline Test 1 & Test 2 & Test 3 & Test 4 & Test 5 & Test 6 & Test 7 & \\
\hline 1.0298 & 1.0296 & 1.0296 & 1.0274 & 1.0298 & 1.0286 & 1.0290 & 1.0286 \\
\hline
\end{tabular}

The Table 3 shows that specific milk weight is moving at the border $1.0274-1.0298 \mathrm{~g} / \mathrm{l}$, the mean value of specific milk weight is $1.0286 \mathrm{~g} / \mathrm{l}$. 


\section{IRITIE}

Ipplied Researrothes in Technics, Technologies and Bductition Journal of the Faculty of Technics and Technologies, Trakia University https://sites.google.com/a/trakia-uni.bg/artte/

Table 4. The results of dry matter in milk

Dry matter in \%

\begin{tabular}{|l|l|l|l|l|l|l|l|}
\hline $\begin{array}{l}\text { Beli } \\
\text { potok }\end{array}$ & $\begin{array}{l}\text { Donje } \\
\text { zuniče }\end{array}$ & $\begin{array}{l}\text { Gornje } \\
\text { zuniče }\end{array}$ & Kalna & Vasilj & Tupižnica & Vina & $\begin{array}{l}\text { Middle } \\
\text { value }\end{array}$ \\
\hline Test 1 & Test 2 & Test 3 & Test 4 & Test 5 & Test 6 & Test 7 & \\
\hline 12.48 & 12.36 & 12.36 & 11.50 & 12.36 & 11.94 & 12.19 & 11.98 \\
\hline
\end{tabular}

The Table 4 shows that dry matter in milk is moving at the border $11.50-12.48 \%$, the mean value of dry matter in milk is $11.98 \%$.

The Table 5 shows that dry matter in milk without fat is moving at the border $7,81-8,49 \%$, the mean value of dry matter in milk is $8,14 \%$.

The results of testing milk quality for making feta cheese by fermentation test by A.Peter based on laboratory testing and comparison with tabelary data found that milk of cheesy type of fermentation, the grub is more or less compact, but compact, and the dried out whey is greenish and slightly acidic.

The Table 6 shows that carbonates are not present in milk.

Table 5. The results of dry matter in milk without fat

Dry matter in milk without fat in \%

\begin{tabular}{|l|l|l|l|l|l|l|l|}
\hline $\begin{array}{l}\text { Beli } \\
\text { potok }\end{array}$ & $\begin{array}{l}\text { Donje } \\
\text { zuniče }\end{array}$ & $\begin{array}{l}\text { Gornje } \\
\text { zuniče }\end{array}$ & Kalna & Vasilj & Tupižnica & Vina & $\begin{array}{l}\text { Middle } \\
\text { value }\end{array}$ \\
\hline Test 1 & Test 2 & Test 3 & Test 4 & Test 5 & Test 6 & Test 7 & \\
\hline 8.49 & 8.43 & 8.43 & 7.81 & 8.45 & 8.14 & 8.27 & 8.14 \\
\hline
\end{tabular}

Table 6. Results of presence of carbonates in milk

\section{Carbonates}

\begin{tabular}{|l|l|l|l|l|l|l|l|}
\hline $\begin{array}{l}\text { Beli } \\
\text { potok }\end{array}$ & $\begin{array}{l}\text { Donje } \\
\text { zuniče }\end{array}$ & $\begin{array}{l}\text { Gornje } \\
\text { zuniče }\end{array}$ & Kalna & Vasilj & Tupižnica & Vina & $\begin{array}{l}\text { Middle } \\
\text { value }\end{array}$ \\
\hline Test 1 & Test 2 & Test 3 & Test 4 & Test 5 & Test 6 & Test 7 & \\
\hline $\begin{array}{l}\text { Not } \\
\text { present }\end{array}$ & $\begin{array}{l}\text { Not } \\
\text { present }\end{array}$ & $\begin{array}{l}\text { Not } \\
\text { present }\end{array}$ & $\begin{array}{l}\text { Not } \\
\text { present }\end{array}$ & $\begin{array}{l}\text { Not } \\
\text { present }\end{array}$ & $\begin{array}{l}\text { Not } \\
\text { present }\end{array}$ & $\begin{array}{l}\text { Not } \\
\text { present }\end{array}$ & $\begin{array}{l}\text { Not } \\
\text { present }\end{array}$ \\
\hline
\end{tabular}

Table 7. The results of alcoholic tests

\begin{tabular}{|l|l|l|l|l|l|l|l|}
\hline \multicolumn{2}{|l|}{ Alcoholic test of milk } \\
\hline $\begin{array}{l}\text { Beli } \\
\text { potok }\end{array}$ & $\begin{array}{l}\text { Donje } \\
\text { zuniče }\end{array}$ & $\begin{array}{l}\text { Gornje } \\
\text { zuniče }\end{array}$ & Kalna & Vasilj & Tupižnica & Vina & $\begin{array}{l}\text { Middle } \\
\text { value }\end{array}$ \\
\hline Test 1 & Test 2 & Test 3 & Test 4 & Test 5 & Test 6 & Test 7 & \\
\hline Not & Not & Not & Not & Not & Not & Not & Not \\
\hline
\end{tabular}

The Table 7 shows that does not gruse.

\subsubsection{Bacteriological tests}

Table 8. Results of bacteriological tests of milk for making feta Bacteriological correctness of raw milk

\begin{tabular}{|l|l|l|l|}
\hline & \multicolumn{4}{|l|}{ Test 1 } & Test 2 & Test 3 \\
\hline Total number of microorganisms & \multicolumn{4}{|l|}{ About 400.000 } & - \\
\hline Staphylococcus aureus & - & - & - \\
\hline Escherichiae coli & - & - & - \\
\hline Clostridium species & - & - & - \\
\hline Proteus species & - & - & - \\
\hline
\end{tabular}

IRTIIE Vol. 6, No. 4, 2018 ISSN 1314-8788 (print), ISSN 1314-8796 (online), doi: 10.15547/artte.2018.04.011 


\section{ARITIE}

Ipplied Researrothes in Technics, Technologies and Bductition

Journal of the Faculty of Technics and Technologies, Trakia University https:///ites.google.com/a/trakia-uni.bg/artte/

The Table 8 shows that milk does not contain harmful microorganisms that could lead to a change in feta cheese.

\subsubsection{Organoleptic tests}

Table 9. Results of organoleptic tests of milk

\begin{tabular}{|l|l|l|l|}
\hline Taste & Smell & Colour & Consistency \\
\hline Mild, nice & $\begin{array}{l}\text { Pleasant, } \\
\text { characteristic, fresh }\end{array}$ & $\begin{array}{l}\text { White or whitish, } \\
\text { uniform }\end{array}$ & $\begin{array}{l}\text { Homogeneous liquid, without } \\
\text { separation of fat bulbs }\end{array}$ \\
\hline
\end{tabular}

\subsection{Results of feta quality testing}

\subsubsection{Physical - chemical tests}

Table 10. Test results of aggregate raw milk before ultrafiltration

\begin{tabular}{|l|l|l|l|l|l|}
\hline${ }^{\circ} \mathrm{SH}$ & $\mathrm{pH}$ & Milk fat in \% & Specific weight & Dry matter in \% & Dry matter without fat \\
\hline 7.0 & 6.64 & 3.841 & 1.0286 & 11.98 & 8.14 \\
\hline
\end{tabular}

The Table 10 shows the basic parameters of the milk from which the concentrated concentrate will be obtained.

Table 11. Test results of concentrate for feta cheese with ultrafiltration

\begin{tabular}{|l|l|l|l|l|}
\hline${ }^{\circ} \mathrm{SH}$ & $\mathrm{pH}$ & Milk fat in \% & Dry matter & $\%$ of moisture \\
\hline 16.6 & 6.54 & 16 & 35 & 65 \\
\hline
\end{tabular}

Table 12. Test results of freshly fetched feta

\begin{tabular}{|l|l|l|l|l|l|l|}
\hline Milk fat & ${ }^{-} \mathrm{SH}$ & $\mathrm{pH}$ & $\%$ of moisture & $\%$ of dry matter & $\%$ of salt & $\%$ of milk fat \\
\hline 16 & 150 & 4,94 & 65 & 35 & - & 45.71 \\
\hline
\end{tabular}

Table 13. Test results for feta in the process of ripening

\begin{tabular}{|c|c|c|c|c|c|c|}
\hline $\begin{array}{l}\% \text { of milk } \\
\text { fat }\end{array}$ & $\begin{array}{l}\text { Milk acidity } \\
\text { o-SH }\end{array}$ & $\mathrm{pH}$ & $\begin{array}{l}\% \text { of } \\
\text { moisture }\end{array}$ & $\begin{array}{l}\% \text { of dry } \\
\text { matter }\end{array}$ & $\%$ of salt & $\begin{array}{l}\% \text { of milk } \\
\text { fat in SM }\end{array}$ \\
\hline \multicolumn{7}{|c|}{ After 15 days } \\
\hline 17 & 206 & 4.72 & 62.98 & 37.02 & 1.93 & 45.94 \\
\hline \multicolumn{7}{|c|}{ After a month } \\
\hline 18.5 & 232 & 4.62 & 62.93 & 37.07 & 1.75 & 49.90 \\
\hline \multicolumn{7}{|c|}{ After a month and a half } \\
\hline 18.7 & 238 & 4.68 & 62.79 & 37.61 & 1.60 & 49.85 \\
\hline \multicolumn{7}{|c|}{ After 2 months } \\
\hline 19 & 240 & 4.66 & 62.61 & 30.40 & 2.45 & 50.80 \\
\hline
\end{tabular}

Table 14. Test results of strength of the rennet

\begin{tabular}{|l|l|l|l|}
\hline Strength of the rennet in minutes \\
\hline Test 1 & Test 2 & Test 3 & Middle value \\
\hline 9,32 & 9.50 & 9.45 & 9.42 \\
\hline
\end{tabular}

$X=4262-1: 42462(10000: 9,42)=42462$.

The ratio spreads and milk is such that $1 \mathrm{~g}$ of the spread can spread $42462 \mathrm{~cm}^{3}$ of milk.

IRTIIE Vol. 6, No. 4, 2018 ISSN 1314-8788 (print), ISSN 1314-8796 (online), doi: 10.15547/artte.2018.04.011 


\subsubsection{Bacteriological tests}

During the examination of the bacteriological tests of the feta, pasteurized and unpasteurized milk and pasteurized concentrate, it was determined that there no present of: Echericiae coli, Staphylococcus aureus, Clostridium and Proteus species. It was found that in pasteurized milk the total number of microorganisms is 30000 in $1 \mathrm{ml}$, in unpasteurized milk 318000 in 1 $\mathrm{ml}$, in pasteurized concentrate 49500 in $1 \mathrm{ml}$.

\subsubsection{Organoleptic tests}

Table 15. Results of organoleptic feta testing

\begin{tabular}{|l|l|}
\hline \multicolumn{2}{|l|}{ Salad cheese soft, Denmark technology } \\
\hline Shape, size, weight & Cubes or squares of per 700-1000 \\
\hline Outside & No edge, white \\
\hline Inside & $\begin{array}{l}\text { Color-white; Consistency-soft, solid on cutting; Smell } \\
\text { and taste-a little sour, picantly; Compatibility-none }\end{array}$ \\
\hline
\end{tabular}

\section{DISCUSSION}

For the production of feta, the milk was used by several producers from several sites, and the characteristics of the cheese directly depend on the quality of the milk. The milk must be completely fresh, hygienically correct and must satisfy the following conditions:

- Must have normal physical and chemical properties: taste, smell, colour, density, fat, properties of fat, proteins and mineral matters, and normal acidity and maturity.

- Must have normal microflora and that under certain conditions can achieve normal maturity.

Fat is directly dependent on milk fat that can vary with certain on milk fat that can vary with certain manufacturers. Milk tests have shown that values move within boundaries 3,69-3,92, with the mean value of 3,84 . The amount of cheese that is obtained from a certain amount of milk depends on milk fat and casein. From $100 \mathrm{I}$ of milk is obtained $20,83 \mathrm{~kg}$ of cheese with $19 \%$ of milk fat. The required milk fat for the production of full fat cheese with $45-50 \%$ of fats should be about 3,5-4\% which depends on the technology itself. Therefore, special attention must be paid to the process of production. Milk must also have a certain degree of acidity, that is must possesses certain maturity, because only the milk of normal maturity gives the pear to be processed properly. Maturity impacts on:

1. Milk coagulation rate;

2. Hardness of pear;

3. Consistency of pear;

4. Speed of whey extraction.

The necessary acidity of milk for making feta moves within the limits of $6,8-7,8^{\circ} \mathrm{SH}$. Based on physical-chemical testing it has been established that the milk used for feta has acidity $7^{\circ} \mathrm{SH}$, taken as a mean value. In order to achieve the desired acidity, the milk is left at $T=30-33^{\circ} \mathrm{C}$ for 60 minutes. The milk concentrate must be pasteurized, and a large number of microorganisms are destroyed in that way. Removing mechanical impurities has a great practical significance because they carry a biological impurity with them. The composition of minerals in cheese plays an important role in organoleptic characteristics and texture of cheese. Concentrate homogenization is applied for the uniform distribution of fat to obtain uniform pear fat. In homogenized concentrate is added a culture of Streptoccocus lactis to a provide a normal microflore. The dilution of the homogenized concentrate is performed under the effect of hymozin and lactic acid on casein. The action of the rennet depends on the

IRTIIE Vol. 6, No. 4, 2018 ISSN 1314-8788 (print), ISSN 1314-8796 (online), doi: 10.15547/artte.2018.04.011 


\section{ARTILE

acidity of the concentrate, because when the acidity is increased, the effect of the rennet decreased. The process of ripening is carried out at a temperature of $14-16^{\circ} \mathrm{C}$ during $2-3$ weeks. The aim of ripening is to obtain cheese with normal quality and good physical, chemical and microbiological parameters.

\section{CONCLUSIONS}

Based on the experimental work, the results obtained, the discussion and the literature data, the following conclusions can be made:

1. The quality of cow`s milk used to produce feta is satisfactory because it possesses all the qualities of quality milk.

2. The quaity of the feta depends on the quality of the milk, concentrate obtained by ultrafiltration and way of producing feta cheese.

3. In the production of feta, it is necessary to constantly keep an account of temperature pasteurization of milk and ultrafiltration, quantity and quality of pasteurized and unpasteurized milk and rennet, temperature of raising and ripening feta cheese.

4. The quality of the obtained feta fully fats meets all the norms prescribed by the rules because it possesses all the qualities of quality soft cheese.

5. This way of making it possible to get a feta in a qiuck and easy manner while preserving the quality of milk and all valuable ingredients.

6. The results of physical-chemical tests of milk showed:

- that the average milk acidity value in producing feta is $7^{\circ} \mathrm{SH}$;

- that the average milk fat value in producing feta is $3,84 \%$;

- that the average specific milk weight value is $1,0286 \mathrm{~g} / \mathrm{l}$;

- that the average value of dry matter is $11,98 \%$;

- that the average value of dry matter withaout fat is $8,14 \%$;

- that there are not carbonates in milk;

- that alcoholic test is negative - milk not grub;

- that milk is bacteriological correctly.

7. The results of feta testing showed:

- after ultrafiltration, milk acidity increased for $9,60 \mathrm{SH}$;

- $\mathrm{pH}$ value increases for 0,1 ;

- dry matter increases for 23,02;

- after a month and half of ripening feta there are increases of $\%$ fat milk, milk acidity, $\%$ fat milk in dry matter and \% salts; and there are decreases of $\mathrm{pH}$ value, $\%$ of moisture and $\%$ dry matter.

\section{REFERENCES}

[1] Proizvodnja sira na tradicionalan način, Prof.spec. Zlatan Glišić (2010).

[2] Proizvodnja mleka i mlečnih proizvoda, Dr.Jovan Đorđević, Dr. Radosav Stefanović.

[3] Principi membranske filtracije sa primenom u tehnologiji mleka, Dr. Dragoljub Đ. Gavrić (1995).

[4] Tehnologija mleka i sirastva, Predrag Puđa.

[5] http://www.tehnologijahrane.com.

[6] Pravilnik o kvalitetu i drugim zahtevima za mleko i mlečne proizvode, kompozitne mlečne proizvode i starter kulture („SI. list SRJ“, br. 26/2002 i „SI. list SCG“ br. 56/2003 dr.pravilnik, 4/2004 - dr.pravilnik 5/2004 i „Sl.glasnik RS“ , br. 21/2009 - dr.pravilnik i 33/2010 - dr.pravilnik). 